\title{
Dilemma of Sexuality Service for Hajj Pilgrims in Saudi Arabia
}

\author{
Agus Multyono ${ }^{1}$, Fakhruddin $^{2}$, Umul Hidayati ${ }^{3}$, Koeswinarno $^{4}$, Edi Junaedi ${ }^{5}$ \\ \{agusmulyono78@yahoo.com\} \\ Research and Development Center for Religious Community Guidance and Religious Services ${ }^{12345}$
}

\begin{abstract}
The topic of husband-wife ties that exists in Saudi Arabia's Hajj pilgrims has been the subject of numerous research rarely before. In addition to being considered a tabu, the government views the issue of sexuality as a private matter for the pilgrims. Then the sequence of problems can be formulated (a) How did the pilgrims in Saudi Arabia react to sexual problems? ; (b) How does the Government make room for pilgrims to address the sexuality problem? The results showed that the issue of sexuality for the pilgrims while in Saudi Arabia was a significant need to be fulfilled, so that organizers of pilgrimages at different levels needed to provide space, particularly for the pilgrimage of a sexually active age. This shows that nearly all productive-age pilgrims tackle the issue of sexuality in different ways while in Saudi Arabia, and are scarcely organized because the hajj organizer does not give them formal space.
\end{abstract}

Keywords: Hajj, sexuality, service, Saudi Arabia.

\section{Introduction}

Sexuality is a private issue, so discussing it in the public domain is not straightforward. The taboo problem is the most basic reason why topics of equal quality rarely appear in the public domain, but the topic of sexuality is increasingly being addressed through media transparency, particularly social media. One of the places where sexuality is then debated in the public domain is the YouTube forum. This material appears to be quite accessible indeed. For the past 10 years, this phenomenon is rarely noticed. More specifically, sexuality-related to husband-wife relationships has also become a more open space for debate, although it is still considered taboo in some areas, especially those related to religion.

For example, the topic of sexuality during the hajj pilgrimage is seldom discussed, while empirically the congregation has a common need. Until now, the pilgrims who have spent an average of more than a month in Saudi Arabia rarely get adequate provisions related to sexuality issues. Though on the other hand, not a few pilgrims leave with a happy age as a married couple. In other words, there are several sexuality issues facing pilgrims of husbands and wives, especially at their productive age while in Saudi Arabia, but they have not yet received an open and organized space for resolution.

The emergence of a phenomenon or at least the term "blessed room" while in Saudi Arabia, it was in fact able to explain how sexuality is a secret, symbolic, tabu issue to be discussed, but it is necessary as the pilgrims' main need, particularly for couples of productive age. That is, for the pilgrims, the topic of sexuality is already known to almost all individual organizers, but they have not "become aware" that this issue should be discussed and resolved. 
As a result, the pilgrims "search" individually for answers, with their expertise, and are performed independently and in secrecy. This is definitely against the current technological and social space growth, which is increasingly opening up opportunities for the sharing of knowledge and experiences based on the rationality and empiricism of life. Issues traditionally considered to be controversial can be found conveniently on YouTube channels. In cyberspace can be found the "land" that was previously locked, secret, shameful, now accessible, and sometimes vulgar. The next question is, will the problem of Jemaah Haji sexuality be permitted to be openly and wildly constructed by each congregation, or will the Ministry of Religion, as the supreme authority, open its "heart and mind" to properly and correctly direct the knowledge and experience of the congregation?

The series of problems can then be formulated (a) How did the pilgrims respond to problems of sexuality while in Saudi Arabia ?; (b) How does the government provide space in overcoming the problem of sexuality for the pilgrims?

\section{Literature Review}

Research on the hajj in Indonesia continues to focus on the service and implementation method, especially on how the pilgrims receive excellent service, from the planning, implementation, until the congregation arrives in Indonesia after the implementation of the haj pilgrimage in Saudi Arabia (Syaukani (eds), 2011); (Abidin, 2017). The service satisfaction index for domestic hajj pilgrims, for example, has continued to grow year after year (Abidin, 2017). On the other hand, although in Saudi Arabia, the Hajj service index is regularly carried out by the Central Statistics Agency, where 1440 H/2019 was very satisfactorily reported with a value of 85.91 .

In the case of Hajj manasik services, there is an inability to efficiently carry out functions such as accountability and official coordination, which contributes to less organization of the execution of rituals (Syaukani, eds, 2009). Concerning manasik, the average value of the Hajj ritual index in 33 provinces obtained from research results on 105 KUAs for implementing manasik guidance in Indonesia was 58.1 percent and the average index for the national manasik guide was 70.7 percent (Jamil et al., 2015). In addition to resolving problems related to the execution of worship and administration, Indonesian pilgrims are also confronted with cultural concerns, in which they frequently have to follow rituals that drain financial resources (Mulyono, et al, 2017).

Seeing the variety of hajj studies, it seems almost forgotten is the congregation's sexuality issue while in Saudi Arabia. Most congregations and officers can still see this problem as tabulating, but it should be noted that the data shows that over 70 percent of Indonesian pilgrims are married couples of sexually active age. Many cases of pilgrims who gave birth in the Holy Land reveals that the pilgrims face many problems with their reproductive health.

\section{Theoretical Framework}

Sexuality in general can be seen from two separate viewpoints, namely between Freud-led naturalists and Foucault-led post-structuralists. According to Freud, sex is an internal drive that comes from the person, then expresses itself to affect socio-cultural conditions. Meanwhile, the inhabitants of Foucaultia, portrayed by J.H. Gagnon and William 
Simon, are of the opposite opinion, that the socio-cultural conditions in each person then promote internal drives.

As for the two views above, their approach has two parallels, namely. First, they both deny that sex is an independent, standing alone zone. There is a natural drive that is both biological in nature and a social interactionist drive. Second, we also see that gender determinants affect the birth of such problems. The Freudians saw Oedipus as the determinant, while the Focaultians saw it as the determinant of historical creation. Thirdly, sex is a regulation factor for both. Freudians perceive themselves (self-repressiveness) as a controller, whereas Foucaultian views social stigmatization as the controller in the context of normalabnormal. Fourthly, we are also searching for the sexuality creation process. Freudians see that sex is derived from the nature of masculinity and femininity, whereas Foucauldians see that sexuality produces femininity and masculinity through the development of powerful social structures all over the world.

Social construction adherents emphasize that self-formation must be understood concerning organic development that continually takes place through social processes (Berger and Luckmann, 1992). Constructivists also explain that somebody can always define the constructs that exist in social space. Therefore, the construction of sexuality depends on how a dialectical relationship results during interaction with the social and cultural environment from social categories and one's experiences (Boswell, 1990). Sexuality becomes a taboo or does not depend on the social space in which it is discussed. Every human being needs to talk about sex but not every social space is open.

Mead shows that there are two similarities in terms of gender and sexuality conceptions, namely the production of social constructions organized into the structure of customary institutions based on mutual consent/community agreement. As an anthropologist, Mead has also succeeded in refuting the views of essentialists who are certainly very positivist, who have seen for decades that the patriarchal structure in society is an impetus to masculine domination which, from a biological perspective, belongs to the male sex (Mead, 1953). Reflecting on Berger's thoughts, an important characteristic of human behavior is mechanistic. In other words, it is the feature of the mechanistic nature that this behavior is reproducible. There is no unique behavior from a person because that action can be reproduced and indeed must be reproducible (Berger, et all, 1992b: 31). The experience of the sexuality of the pilgrims was produced and then reproduced by the following pilgrims and so on. Why is this so, because there are no or no shared lessons that are textualized, except for individual knowledge and experience which is then passed on.

\section{Research Methods}

This research is qualitative by using in-depth interviews with productive age pilgrims (17-50 years), the pairs of pilgrims being the focus of the research were pilgrims in 2017, 2018 , or 2019, with the hope that they would remember well the actual events during Hajj trips, particularly those related to the experience of a husband-wife relationship while in Saudi Arabia. The strategy of gathering data through interviews by addressing sexuality in Indonesian culture is not a simple problem that tends to taboo the sexual discourse. That is why the interview in this research involved an extreme closeness between the researcher and the married couple who were the subjects of the study so that they could be genuinely available when the interview was conducted. This research succeeded in interviewing 18 
couples of pilgrim husbands and wives, all of whom were able to describe freely the things they encountered during the pilgrimage.

Interviews with some flight group advisors (Group), KBIHU advisors, leaders of mass organizations, and the Hajj division of the Ministry of Religious Affairs, Regency/City were also conducted to discuss interactions related to the sexuality of pilgrims while in Saudi Arabia. The study was carried out in the City of Yogyakarta, Kebumen Regency, Central Java, Depok City, West Java, and Madiun City, East Java.

\section{Homeland to Holy Land}

The regular hajj pilgrimage average of 42 days leaves the house. At the embarkation, the congregation generally stays overnight which is busy with preparations, administration, finances and equipment checks, health checks, and short manasik. This busyness is barely felt because generally they are filled with happiness and curiosity to arrive at the Holy Land soon.

Generally, the congregation occupies separate rooms between men and women. On average, one room in Mecca is filled with 4-6 people, while in Medina the largest part of a hotel room is filled with 4 people. Married couples usually occupy different rooms which are adjusted based on the husband and wife partner as well. In Medina, generally two rooms whose contents are paired with each other can be close to each other, but in Mecca, in several cases, men's and women's rooms are not always close together, although the Hajj committee always tries to keep the room between husband and wife not too far away. This division is usually based on the existence of the team, so that a team is usually divided into 2 to 3 rooms. The division is such that it is "unlikely" that one room will consist of men and women. This division of rooms is fully controlled by the Group Chair.

Several small cases show that, although the possibility of a single room being not occupied by men and women has been minimized, but there are just chance 2 or 3 couples who 'insist' on being in one room. Generally, a husband and wife's bed is insulated with a sheet or other cloth, which can be a cover between the husband and wife's beds. These bulkheads are made "creatively" by the congregation, who are generally independent congregations.

\section{Sexuality: Taboos and Needs}

It is between these routine activities that most of the productive-age congregation slowly begin to feel the rise of sexual impulses. They consider an all-meat diet to be the main cause of this sexual urge to arise, particularly among men. The Government's regular food menu includes meat, poultry as well as beef, lamb and probably camel meat. Meat is considered a vital sex drive trigger, since it is rich in fat. Red meat is rich in zinc in many cases, a nutrient that retains testosterone (male sex hormone) while increasing the fertility and libido.

Time spent with husband and wife is also an important factor outlining why sexual urge occurs. Although this togetherness also takes place as in their respective homes, the separation of the bedrooms of men and women triggers an atmosphere of longing "which is different from ordinary days" between married couples. Always together but unable to "touch" each other is seen by some male congregations as a "torture". Often the husband and wife congregation looks more intimate and warmer than the daily conditions at home. This is due to a different "taste", where "taste" is difficult to define but there is a change in their body's 
reaction. "If holding wife's hand, it feels like trembling. Even though at home it's just so-so ". "I often don't feel like I'm wringing my wife's hand when I walk hand in hand, even though I've never done it before at home." Almost all male congregations of reproductive age experience such expressions and feelings.

For a wife, wringing hands or holding hands is read as a sign. They knew exactly what had happened, but of course they didn't just respond. "I know, and I realize", "I feel sorry sometimes", is a sign reading that the wives respond to. There is a kind of indefinable taste that causes the sexual urge or stimulation to arise. Something said by Freud (2003: 118) that a certain level of social tension is indispensable for the process of stimulating the erogenous zone.

Sexual drive comes in different ways. Some of the male congregation felt unable to focus on acting and thinking, were anxious, and some even got angry with no clear cause. Husbands feel this kind of behavior is true, and it is also understood by wives. Sometimes this kind of condition in some cases can occur within a few days until then find a solution to the problem. There is nothing to hide when sexual urges arise, although not always in verbal language. The husband's symbolic language and body movements are clearly legible. In such situations, a way out is not always sought, but it is compensated through various rituals of worship, such as prayer, dhikr, or even trying to be forgotten. Forgetting and avoiding sexual urges is not an easy job, especially for men.

The male congregation had a dominant sexual drive before the female congregation. Even some male congregations have started to appear sexually driven, 2 days after arriving in Saudi Arabia, both in Medina for wave 1 and in Mecca for wave 2. Women are in the position to follow men, although it is recognized by female congregations that this need is a mutual needs. There were no cases where the first sexual urge was more than 4 days in Saudi Arabia. Often the question of this kind of event is associated with the colloquial term lust. Yet it is not a matter of lust big or small, strong or weak, appropriate or inappropriate. Sexuality must be seen from biological essence and needs. From the essence side, sex is always translated into the meaning of the nature of sex itself. Meanwhile, in terms of biological needs, sex is always seen as a natural human need (Hikmawan, 2006: 355). Because of natural necessity, it is a matter of time, how long the sexual urge to appear, is very relative. Like the need to eat or drink, how much rice will be taken from one person to another must be different. Regarding the frequency of sexual intercourse in Saudi Arabia, on average, it ranges from 2-6 times. Once in Medina, and the rest was done in Mecca.

It can also be clarified logically, about the consistency of a married couple's closeness every day. Nearly all congregants interviewed for married couples were couples who met every day and were at home. That is, there were no married couples in this case who experienced long-distance relationships, so they were not used to being apart from their spouses for more than 2 days. It was estimated that after arriving in Saudi Arabia not too long ago this disorder caused sexual appetite to emerge towards wives. This fact demonstrates how the mind is then continually trying to reflect the truth, or that truth may be created because of the orders in the thought framework. Not all social truth is taken for granted. Truth is a reality that originates from thoughts and actions and is sustained by thoughts and actions as actual (Berger and Luckmann, 1990: 29). Sexual desire occurs not only because people think of sex, but because is faced every day when expressing the urge itself together with a partner.

Some congregations try to "avoid it" by carrying out worship activities, such as zikr, reading more of the Al-Quran, and increasing the number of sunnah prayers in the mosque. This strategy was conveyed by the pilgrimage supervisor in the group. The result was more failures than successes. Sexuality is the energy that can drive every human activity. Sexuality 
is not merely seen as a related activity or conjugal relationship, but more than that it can be a great energy in driving healthy activities and thoughts.

Every human movement is an affection which is a combination of emotions and ratios that require a carrying capacity capable of dynamizing life and creativity. One part of the carrying capacity is biological needs. Starting from the desire to sleep, eat drinking and sex, of course. Of all the debates that occur against all human needs, it seems that sex occupies the most controversial position and continues to be a discussion throughout human civilization. Essentially, sex is a major part of the desire to fulfill bodily needs. It is part of the consumption needed by the body. Borrowing the term Pasi Falk (1994), sex is also part of the corporeality of the body. In the same way, it can be explained that in the view of social constructs, sex is a historical unification formed through two main conceptions, namely sex as an area of relationship (partner) and sex as a unit of social unity.

Broadly speaking, there are two views in responding to the conception of sexuality, namely essentialists and non-essentialists. The first view conceptualizes sex as something instinctive and biological. This view tends to be reductionist towards the social values that develop in the middle. Essentialists such as Sigmund Freud, Alfred Kinsey Virginia Johnson, William Masters. Most of them have a background in psychology, medicine, psychiatry, and biology. Meanwhile, the non-essentialist view sees that sex is not a gift that is ascribed/taken for granted. It exists and is shaped by dialectics and social control. In other words, the need for sexual relations is not merely the fulfillment of biological and psychological needs, more than that there is a social dialectic between self and the environment. This means that the fulfillment of sexual needs has 3 dimensions at the same time, namely biological, psychological, and social dimensions.

Through the energy of sexuality, all activities of a person are automatically reflected. Some experts even show that husband and wife sexual relations are not just a biological, psychological, or reproductive activity, but can also produce more productive activities (Fromm, 2002: 65). If it is related to the wider life, it shows that sexuality is closely related to success or failure in human life. People with successful lives have a healthy sexual life. In the same way, it can be said that healthy sexuality affects the biological, psychological, and social health of humans. Sexuality no longer has to be taboo because it is considered to be against norms and ethics. On the contrary, when sexuality is hidden on the basis of norms and ethics, what happens is violations of norms and ethics themselves. Cases of pornography, sexual harassment, and the like occur, among others, because sexuality is always hidden on the pretext of norms and ethics.

Sexual energy is not only useful for the body, but also as an emotional burner. This creates a warm, comfortable, and relaxing energy in the body. Sexual imbalance can lead to blurred, unfocused, or distorted thoughts and uncontrollable emotions. Balanced sexual energy can produce creative thoughts and positive encouragement to act positively. In other words, the position of sexual energy must be used appropriately, not under pressure, or trying to be eliminated. Suppressing sexual energy is like pressing ping-pong balls into the water. The more we try to suppress, the more he looks for a way out elsewhere.

The question of taboo or not about sexuality is a result of social construction. As Berger and Luckmann (1992) say that the relationship between oneself and the environment is dialectical. Humans are producers of objective social realities through a process of externalization, which then as an objective reality affects them again through the process of internalization. In other words, Berger claims that society is a product of culture, and at the same time people are a product of society. The question of taboo in sexuality is very much dependent on how humans see sexuality as an empirical need or as a cultural product. In 
certain groups of society, sexuality is no longer a matter of sexuality taboos, because many media channels have discussed it openly, but in other groups, the issue of sexuality is still relatively closed to discuss.

The two groups then produce different societal products. One produces congregational groups that are open, egalitarian, and can accept sexuality such as the need for food and drink that can be discussed openly, the other produces congregational groups that are closed and tend to avoid discussions of sexuality. That's the externalization process. On the other hand, individuals with introverted habits in sexuality, due to media exposure and the increasingly open cultural space, in turn, will be more open in discussing issues of sexuality. Or, even though individuals have an open attitude towards sexuality, they are not in an open socio-cultural space, then they do not become open. That is the internalization process in social construction. In other words, there is a dialectical process between oneself and the social environment so that culture is created. However, it must be admitted that the more educated congregations are more open to discussions of sexuality. Berger, Berger, Kellner (1992: 65) did find a box that has created to a lifestyle, mindset, and taste style. In other words, sexuality is more of a form of sexual behavior, values, norms, ethics, which are directed at certain interests by certain parties (Arifki, 2015: 1).

\section{Problem Solving Strategy}

It can be said that all group leaders, regular worship guides, and worship guides from KBIHU understand the sexual problems faced by a married couple of pilgrims when in Saudi Arabia. Generally, they go to become hajj officers not only once, even for KBIHU supervisors who have departed a dozen times. "There are those who often get angry for no reason", "I have been there to be a guide many times, I already know these things", "It's funny too, but how is that a necessity". Such statements emerged among Hajj officials, both regular pilgrims from the Ministry of Religion and the KBIHU, during in-depth interviews.

The issue of sexuality was relatively never discussed during the manasik, especially the regular manasik conducted at the KUA or the local Ministry of Religion. When one by one the congregation starts to appear sexually motivated, several solutions are usually built on the agreement between the head of the group, the worship guide, and among the congregation itself. First, some congregants who have participated in the KBIHU program, generally the KBIHU supervisor has coordinated with the team leaders. The division of team members usually takes into account the division of gender and pairs of congregations, as well as family groups, so that the division of rooms for the congregation also follows this composition.

KBIHU in several cities, such as Yogyakarta City and Depok City, for example, have long discussed the issue of sexuality openly during manasik. KBIHU usually uses existing rooms by dividing the rooms into pairs. For example, room A consists of 4 men, while room B consists of the wife of the male partner of room A. In this way, in one day or "one cycle of time" rooms A and B can be used jointly by 2 couples, husband and wife respectively.

Some methods are coordinated, the room keys are deliberately handed over in turns, but some are symbolic with certain codes that are mutually agreed upon. The congregation who carries the keys are those who have the right to use. Whereas those who use symbols, for example, if the wife delivers coffee in her husband's room, this means that the other congregation will leave for the mosque earlier, or they do not return to the hotel for 2 or 3 
obligatory prayers. Usually, it ranges from Dzuhur to Maghrib prayer. This symbol can be in various forms and methods, depending on the previous agreement.

The problem that arose was when the team contained elderly congregations. Elderly congregants usually rarely pray at the mosque, especially when in Mecca. In addition to the question of the distance that is not too close, we are usually faced with a rather hot weather, especially during Dzuhur and Asr. In addition, the younger congregation felt reluctant to "force" them to do activities outside the room.

Second, the congregation who is more introvert usually only takes advantage of limited time, in several places, such as a place to dry clothes. Almost every hotel in Mecca provides a place for drying clothes on the top floor. This is because the length of stay in Mecca is longer than in Medina. Apart from being quiet at certain hours, these places for drying also have ample space. When there are a lot of congregational clothespins, this large area is sometimes used by some congregants for quick sexual intercourse or what is called quick sex. "Quick sex is very suitable for young couples who are both incredibly busy," said Dr. Ferryal Loetan, Sp.RM, MMR. Of course this method contains many risks, but with very high caution, some informants actually made experiences and sensations that they had never done before.

Quick sex may also be done in each congregation's quarters, during the mosque 's compulsory prayers or study activities that are normally conducted massive numbers in one group or another. Quick sex can also be achieved with some touches or movements and not necessarily by penetration.

Third, in a few cases, pilgrims were found using hotel reservation applications, such as Traveloka, Agoda, or others. An informant explained that he had used the Traveloka application once, and obtained a hotel for more than IDR 2 million. However, another informant said that during the Hajj season, almost all hotels, both in Mecca and Medina, had all been contracted for the benefit of the congregation, because when they tried to go around looking for hotels they would have been rejected.

Fourth, in collaboration with Hajj season workers or hotel guards to get rooms that are rented for the night. The rates for the stay may vary, depending on the congregation's approach to them. This method is the safest way and is considered by some congregations to be free from disturbances and at a cost that is not too expensive. In fact, in a few cases, pilgrims who work in Saudi Arabia - Mecca and Medina - rent out their dorm to be lent to congregations.

Fifth, by taking advantage of the empty rooms left by the congregation for Medina. Four or five days after the implementation of the Hajj ritual of 8-12 Zulhijah, the congregation is actually just waiting for the queue to return to Indonesia or for those who enter Wave 2 then move towards Medina. This means that in one hotel the conditions vary greatly, not then one hotel is left by the congregation at the same time. This is where some rooms start to empty, so that pilgrims who have not left the hotel can take advantage of it. This method must also be careful, because the average room is not locked, so that anyone can easily open the door. Unless the congregation personally borrows the hotel key through the office boy.

Sixth, by utilizing muthawif (hajj guide) houses, especially for KBIHU which are quite large and utilizing muthawif. This method takes time, because usually the distance between the hotel and Muthawif's house is quite far. Seventh, by taking advantage of the "baraka rooms" that are often offered by restaurant stalls, which provide rooms. This method is cheaper, but usually the room facilities are not very good, and some congregants "feel" uncomfortable this way. 


\section{Conclusion}

The hajj organizers have not paid full attention to meeting the husband and wife's sexual needs for the pilgrims. Indeed, it has never emerged empirically and has become an issue, because sexuality is still seen as a taboo topic to be openly discussed. Sexuality must be treated as a fundamental need, such as eating and drinking, since human psychological and biological needs must be in a balanced role, in addition to physical requirements. That doesn't mean the congregation is neglecting these needs, however. They carry out strategies separately, individually, and secretly in meeting these basic human needs, particularly for pilgrims of productive age.

The congregation, in fact, often experiences sexual impulses and appears in Saudi Arabia only within 4-5 days. The phrases that occur more commonly in male congregations are tension, wanting to be upset, and confused than women. This does not mean that the female congregation is not articulate, the issue is a matter of culture and social construction, in which women in sexual matters can not be articulated as opposed to men.

Nearly all pilgrimage officials in the regions believe it is important to provide space regarding the knowledge of sexuality of married couples, particularly how the strategy to meet their needs while in Saudi Arabia. Since the approaches and techniques used so far to meet a married couple's sexual needs while in Saudi Arabia are not systematic, and seem to run each with different risks. Ironically, the government hardly gives space to solve the problem of sexuality, since the issue is considered to be a personal need of each congregation, and the Hajj committee is considered to have facilities given to it as taboo.

\section{References}

[1] Abidin, Zaenal (eds), 2017. Survei Pelayanan Haji di Indonesia, Jakarta: Puslitbang Bimas Agama dan Layanan Keagamaan

[2] Arifki, 2016. "Konstruksi Seksualitas dalam Keluarga (Studi terhadap Undang-Undang No. 1 Tahun 1974 Tentang Perkawinan dan Kompilasi Hukum Islam)", Musawa, Vol. 15, No. 1 Januari 2016, hal 1-19

[3] Berger, Peter L, 1994. Langit Suci: Agama Sebagai Realitas Sosial, Jakarta: LP3ES

[4] Berger, Peter L, Brigitte Berger, Hansfried Kellner, 1992. Pikiran Kembara: Modernisasi dan Kesadaran Manusia, Yogyakarta: Penerbit Kanisius.

[5] Berger, Peter L dan Thomas Luckmann, 1992. Tafsir Sosial atas Kenyataan, Jakarta: LP3ES

[6] Boswell, John, 1990. "Categories, Experience, and Sexuality", dalam Edward Stein, Forms of Desire: Sexual Orientation and The Social Constructionist Controversy, New York and London: Routledge, hal. 133-173.

[7] Fromm, Erich, 2002. Cinta, Seksualitas, Matriarki, Gender, Yogyakarta: Jalasutra.

[8] Hikmawan, Rusydi, 2006. "Manifestasi Seksualitas dalam Budaya Kebebasan", Ulumuna, Volume X Nomor 2 Desember, hal. 347-366

[9] Jamil, Abdul (eds), 2015. Pelaksanaan Bimbingan Manasik Haji oleh Kantor Urusan Agama, Jakarta: Puslitbang Kehidupan Keagamaan.

[10] (eds), 2017. Efektifitas Bimbingan Manasik pada Haji Reguler dan Khusus di Arab Saudi, Jakarta: Puslitbang Bimas Agama dan Layanan Keagamaan 
[11] Koeswinarno (eds), 2014. Efektifitas Kelompok Bimbingan Haji dalam Memberikan Pelayanan dan Bimbingan terhadap Jamaah Haji di Indonesia dan Arab Saudi, Jakarta: Puslitbang Kehidupan Keagamaan

[12] Mead, Margaret , 1953, Sex and Temperament In Three Societies. Amentor Book.

[13] Mulyono, Agus, et all, 2017. Tradisi Haji di Beberapa daerah di Indonesia, Jakarta: Puslitbang Bimas Agama dan Layanan Keagamaan

[14] Pasi Falk, Pasi, 1994. The Consuming Body, London: Sage Publications Ltd.

[15] Syaukani, Imam (eds), 2009. Manajemen Pelayanan haji di Indonesia Jakarta: Puslitbang Kehidupan Keagamaan

[16] , 2011. Kepuasan Jamaah Haji terhadap Kualitas Penyelenggaraan Ibadah Haji Tahun 1430 H/2009 M, Jakarta: Puslitbang Kehidupan Keagamaan. 